\title{
Carbon Use Efficiency of the First Ratoon Cane by Eddy Covariance Technique
}

\author{
Tiwa Pakoktom, Nongpat Chaichana, Jessada Phattaralerphong, and Jate Sathornkich
}

\begin{abstract}
The propose of this study was to evaluate $\mathrm{CO}_{2}$ flux and accumulative $\mathrm{CO}_{2}$ absorbance of the first ratoon cane by using Eddy Covariance Technique. First ratoon cane was produced at Cane and Sugar Industry Promotion Center, Kanchanaburi province, from June 2010 to April 2011. From the results, the $\mathrm{CO}_{2}$ flux was fluctuated from -2.4 to 2.8 $\mathrm{mgCO}_{2} \mathrm{~m}^{-2} \mathrm{~s}^{-1}$. The negative values showed in the day time and it means $\mathrm{CO}_{2}$ was absorbed by plant via photosynthesis. On the other hand the positive values means $\mathrm{CO}_{2}$ was emitted by plant and soil respiration in night time. Different $\mathrm{CO}_{2}$ flux was observed in each growth stages. $\mathrm{CO}_{2}$ flux was lower at germination stage (June 2010) and the total $\mathrm{CO}_{2}$ absorbance at this stage was $63.1 \mathrm{gCO}_{2} \mathrm{~m}^{-2}$. $\mathrm{CO}_{2}$ flux reached its maximum at stalk elongation stage (September 2010-January 2011) and total $\mathrm{CO}_{2}$ absorbance at this stage was $2,448.3 \mathrm{gCO}_{2} \mathrm{~m}^{-2}$. Totally, $\mathrm{CO}_{2}$ absorbance for the entire period of experiment was $4,300.4$ $\mathrm{gCO}_{2} \mathrm{~m}^{-2}$. Carbon use efficiency of the $1^{\text {st }}$ ratoon cane was 2.13 tyield/tCOO $\mathrm{CO}_{2}$. From the results, it was concluded that the $1^{\text {st }}$ ratoon sugarcane ecosystem was a $\mathrm{CO}_{2}$ source during night hours and $\mathrm{CCO}_{2}$ sink during the day time. Finally, for the entire growing season the $1^{\text {st }}$ ratoon cane system is the sink of $\mathrm{CO}_{2}$.
\end{abstract}

Index Terms-Carbon use efficiency, eddy covariance technique, first ratoon cane.

\section{INTRODUCTION}

Sugarcane is an important economic crop in Thailand and the world not only for sugar production but increasingly also for a bioenergy crop due to its phenomenal dry matter production capacity [1]. Global sugarcane production now is estimated at 1,250 million tons a year while the total production of sugarcane in Thailand is about 106 million tons per year. Total planting area of sugarcane in Thailand is 1.42 million ha [2]. Carbon dioxide $\left(\mathrm{CO}_{2}\right)$ exchange between terrestrial ecosystem and the atmosphere one of the key process that affects atmospheric $\mathrm{CO}_{2}$ concentration. In order to assess the role of the terrestrial ecosystem in the global $\mathrm{CO}_{2}$ budget at present, and to predict its changes in the future under global warming, long-term observation of $\mathrm{CO}_{2}$ exchange has been done in various ecosystems in the world [3], [4]. These observation sites are mostly located in forest

Manuscript received March 5, 2013; revised May 8, 2013. This work was supported in part by the Office of the Cane and Sugar Board, Thailand.

T. Pakoktom and N. Chaichana are with the Department of Agronomy, Faculty of Agriculture at Kamphaeng Saen, Kasetsart University, Kamphaeng Saen Campus, Thailand (e-mail: agrtwp@ku.ac.th; nongpat.chai@gmail.com).

J. Phattaralerphong is with the Faculty of Natural Resource and Agro-Indrustry, Kasetsart University, Chalermprakiat Sakon Nakorn, Thailand (e-mail: csnjdp@ku.ac.th).

J. Sathornkich, is with the Department of Horticulture, Faculty of Agriculture Kasetsart University, Bangkok, Thailand (e-mail: psdjate@ku.ac.th). ecosystems because these are believed to the be most influential terrestrial ecosystem in the global $\mathrm{CO}_{2}$ budget. However, non-forest ecosystem, such as grasslands, wetland or agricultural field also cover some part of the land area and contribute to regional and global $\mathrm{CO}_{2}$ budgets [5]. Gas fluxes can be measured using many methods and Eddy Covariance Technique (EC) is the new method which does not interfere with process of gas exchange between the surface source and the atmosphere [6]. This technique has been used to measure $\mathrm{CO}_{2}$ flux, and many studies have been published [7]. However, most of gas exchange studies involved short-term measurements. In this paper, we present seasonal variation of $\mathrm{CO}_{2}$ flux at a customarily cultivated single cropping sugarcane crop base on the results of a single season-long measurement of $\mathrm{CO}_{2}$ flux using the $\mathrm{EC}$ technique.

\section{MATERIAL AND METHODS}

\section{A. Site Description and Period of Measurement}

This site was conducted at the first ratoon cane which is locates at Cane and Sugar Industry Promotion Center, Kanchanaburi province, in Western Thailand. The site is located at latitude $14.03^{\circ} \mathrm{N}$ and longitude $99.68^{\circ} \mathrm{E}$ with an elevation of $22.37 \mathrm{~m}$ above mean sea level. The soil of the sugarcane field is sandy loam. $\mathrm{A} \mathrm{CO}_{2}$ flux measurement and meteorological tower was $6.0 \mathrm{~m}$ high and was erected in the center of plot area. The sugarcane fields around the tower were managed as single sugarcane-cropping fields following by a common management in this area. In this study, the data of the $1^{\text {st }}$ ratoon cane growing season (9 June 2010-31 April 2011) were analyzed.

\section{B. Meteorological Data Measurement}

The meteorological parameter consisted of solar radiation (Rs), net radiation $(\mathrm{Rn})$, total amount of rain, wind speed and wind direction, air temperature and relative humidity. All of the meteorological instruments were installed on the tower at a height of $6.0 \mathrm{~m}$. The meteorological data were collected and averaged every 30 minutes and stored in data logger CR1000 (Campbell Scientific, Inc.).

\section{Plant Growth}

Plant-cane was planted in 30 June 2009 and the first ratoon cane started from 9 June 2010. Growth characteristics consisted of plant height, stem diameter, fresh and dry weight, leaf area (LA) and leaf area index (LAI). The samples were taken from 5 plots around the tower at monthly intervals commencing from 60 days after plant-cane was harvested 
until the next harvest. Each samples consisted of the above-ground portions of all shoots, the shoots were separated into stem, leaf blade and leaf sheath. When the amount of sample was in excess, a portion of representative subsample was used for dry weight determination, extrapolated for a whole sample, which was designated as the total dry matter. All samples were oven-dried at $80^{\circ} \mathrm{C}$ until a constant weight was reached. Sugarcane growing stage separated by four different growth stage, comprising germination and emergence, tillering and canopy establishment, grand growth, and maturation which are 1, 2, 7 and 2 months in length, respectively [8].

\section{Eddy Covariance Flux Measurement}

$\mathrm{CO}_{2}$ flux was measured by the Eddy Covariance technique. Three components of wind velocity and temperature fluctuation were measured with a sonic anemometer (CSAT-3; LI-COR, Inc., Lincoln, NE, USA). The density of $\mathrm{CO}_{2}$ was measured with an open-path infrared gas analyzer (IRGA) (LI-7500; LI-COR, Inc., Lincoln, NE, USA). The sensor heads of the sonic anemometer and IRGA were mounted the tower at a height of $2.0 \mathrm{~m}$ above the plant canopy. The data from the sonic anemometer and IRGA were sampled at $20 \mathrm{~Hz}$ using a 16-bit digital data recorder and stored in data logger CR3000. Half-hourly flux density of the $\mathrm{CO}_{2}$ was calculated from the covariance between the vertical wind velocity and the respective quantities. All data were downloaded to computer every week and the quality of data were checked against the standard meteorology [9]. The $\mathrm{CO}_{2}$ flux data were shown in plus $(+)$ and minus $(-)$, the meaning of plus is $\mathrm{CO}_{2}$ was released from ecosystem by plant and soil respirations to atmosphere, and minus indicated $\mathrm{CO}_{2}$ was absorbed into crop community through photosynthesis.

\section{E. Carbon Use Efficiency (CUE)}

Carbon use efficiency (CUE) was the ratio of net primary production (NPP) to gross primary production (GPP), describes the capacity of plants to transfer carbon from the atmosphere to biomass [10]. CUE is equivalent to CUE = NPP/GPP [11], [12].

\section{RESULTS}

\section{A. Meteorological Data}

Meteorological condition in the first ratoon cane during 9 June 2010-30 April 2011 was shown in Fig. 1. Daily average solar radiation (Rs) variation ranged from 3.29-27.56 $\mathrm{MJm}^{-2} \mathrm{~d}^{-1}$, lower levels of solar radiation in March 2011. Net radiation $(\mathrm{Rn})$ was increased after the sunrise and reached its maximum at noon. The daily average of $\mathrm{Rn}$ variation ranged from 0.63-22.55 $\mathrm{MJm}^{-2} \mathrm{~d}^{-1}$. The trend of average air temperature $(\mathrm{Ta})$ and average relative humidity $(\mathrm{RH})$ were shown in Fig. 2. The time series of average air temperature (Ta) fluctuation was between $17.9-31.1^{\circ} \mathrm{C}$, its minimum was $17.9^{\circ} \mathrm{C}$ in March 2011 and its maximum was $31.1^{\circ} \mathrm{C}$ in April 2011. The average relative humidity (RH) was $71 \%$ and its minimum was $53 \%$. Total amount of rain fall during the study period was $345 \mathrm{~mm}$ and its maximum was $61.1 \mathrm{~mm}$ per day which occurred in 29 June 2010 (Fig. 3).

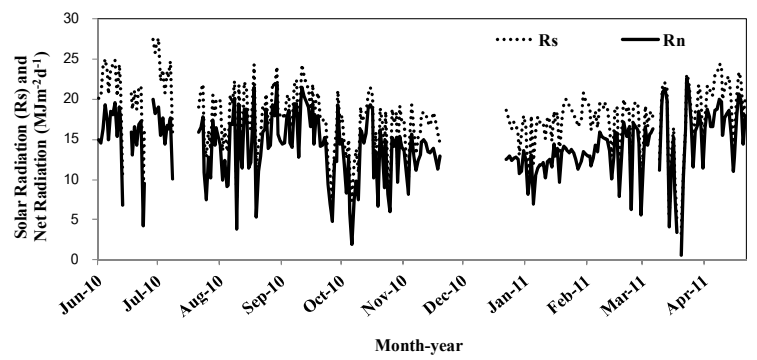

Fig. 1. Time series of solar radiation (Rs) and net radiation $(\mathrm{Rn})$ at the experimental site from 9 June 2010-30 April 2011.

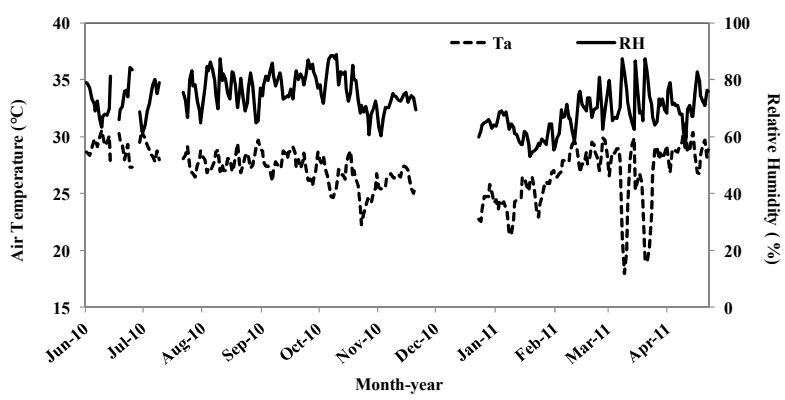

Fig. 2. Time series of average air temperature (Ta) and average relative humidity (RH) at the experimental site from 9 June 2010-30 April 2011.

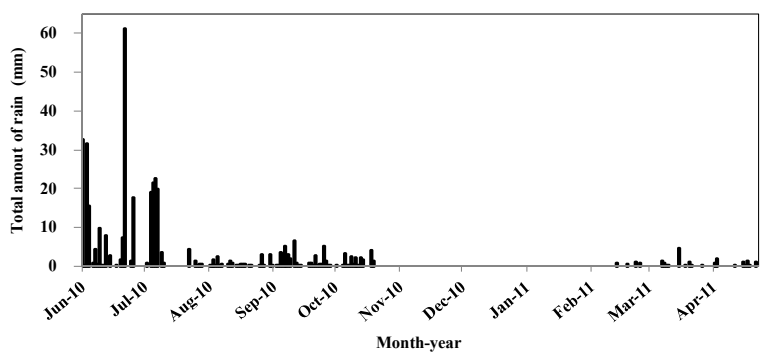

Fig. 3. Total amount of rain at the experimental site during 9 from 2010-30 April 2011.

\section{B. Plant Growth Parameter}

Plant height and diameter increased gradually from the beginning of measurement and reached the saturated point at age 7 month. Plant height was reached a maximum of 268.7 $\mathrm{cm}$ at maturity stage. The LAI showed a gradual increase from the tillering stage and reached a maximum at stalk elongation stage (Fig. 4)

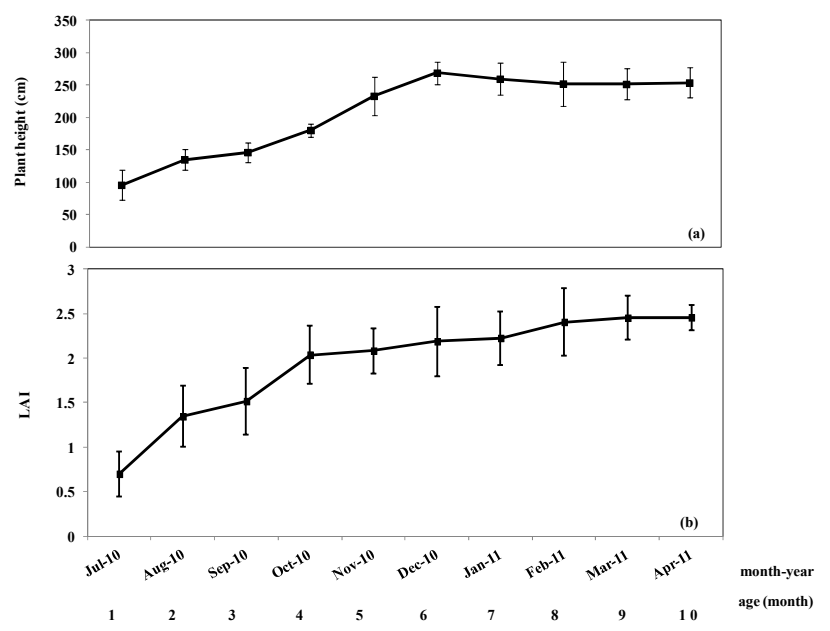

Fig. 4. The plant height $(\mathrm{cm})$ and leaf area index (LAI) of the first ratoon cane. 


\section{Daily Trend of $\mathrm{CO}_{2}$ Flux}

All the data set of the first ratoon cane were analyzed for the daily trend of $\mathrm{CO}_{2}$ flux. The daily trend of $\mathrm{CO}_{2}$ flux was presented in Fig. 5. Throughout the measurement period, the daily values ranged from $-0.5 \mathrm{mgCO}_{2} \mathrm{~m}^{-2} \mathrm{~s}^{-1}$ to 0.13 $\mathrm{mgCO}_{2} \mathrm{~m}^{-2} \mathrm{~s}^{-1}$. It can be inferred that the fluxes of $\mathrm{CO}_{2}$ were always positive during night hours with an average night time value of $0.11 \mathrm{mgCO}_{2} \mathrm{~m}^{-2} \mathrm{~s}^{-1}$, whereas during the day time the flux was negative with a corresponding value of -0.17 $\mathrm{mgCO}_{2} \mathrm{~m}^{-2} \mathrm{~s}^{-1}$. Total $\mathrm{CO}_{2}$ released of $4.8 \mathrm{gCO}_{2} \mathrm{~m}^{-2}$ and total $\mathrm{CO}_{2}$ absorbed of $12.4 \mathrm{gCO}_{2} \mathrm{~m}^{-2}$ were observed.

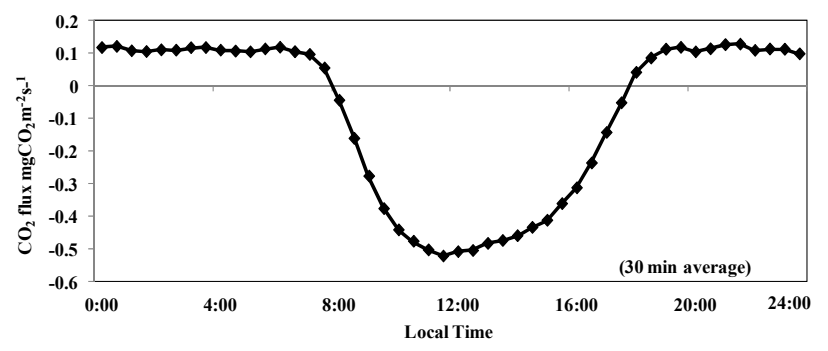

Fig. 5. Daily trend of $\mathrm{CO}_{2}$ flux of the first ratoon cane from 9 June 2010-30 April 2011.

\section{Daily Trend of $\mathrm{CO}_{2}$ Flux in Each Growing Stage}

In each growing stage daily trend of $\mathrm{CO}_{2}$ flux was similar, the daily trend of $\mathrm{CO}_{2}$ flux were increased in early morning and reached it maximum at noon then it was decreased in the afternoon. On the other hand, this variance of $\mathrm{CO}_{2}$ flux in each growing stage. In germination, tillering, grand growth and maturation the variation range between -0.16 to 0.26 , -0.54 to $0.20,-0.61$ to 0.12 and -0.42 to $0.13 \mathrm{mgCO}_{2} \mathrm{~m}^{-2} \mathrm{~s}^{-1}$, respectively (Fig. 6.)

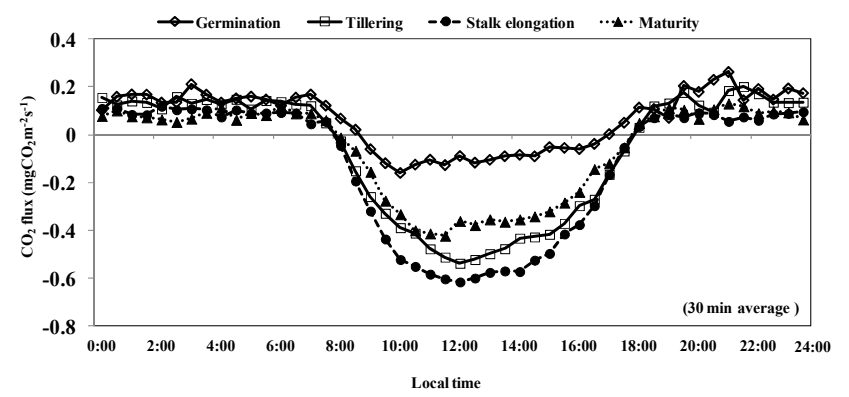

Fig. 6. Daily trend of $\mathrm{CO}_{2}$ flux in each growing stage of the first ratoon cane from 9 June 2010-30 April 2011.

\section{E. Seasonal Trend of $\mathrm{CO}_{2}$ Flux}

Seasonal variation of $\mathrm{CO}_{2}$ flux was shown on Fig. 7. The daily values ranged between 0.05 to $31.1 \mathrm{gCO}_{2} \mathrm{~m}^{-2} \mathrm{~d}^{-1}$. The $\mathrm{CO}_{2}$ flux summation at germination stage (0-1 month), tillering stage (2-3 month), stalk elongation stage (4-8 month) and maturity stage (9-11 month) were 63.1, 838.2, 2,448.3 and $950.8 \mathrm{gCO}_{2} \mathrm{~m}^{-2}$, respectively. At stalk elongation stage the $\mathrm{CO}_{2}$ flux reached maximum cause of high LAI and this period which are 5 months in length. Totally, $\mathrm{CO}_{2}$ absorbance of $4,300.4 \mathrm{gCO}_{2} \mathrm{~m}^{-2}$ of the $1^{\text {st }}$ ratoon cane was recorded.

\section{F. Carbon Use Efficiency of the $1^{\text {st }}$ Ratoon Cane}

Throughout the $1^{\text {st }}$ ratoon cane growing season, sugarcane biomass was 83.75 ton/hectare. And the $1^{\text {st }}$ ratoon cane field can be absorbed $\mathrm{CO}_{2} 4,300.4 \mathrm{gCO}_{2} \mathrm{~m}^{-2}$. Carbon use efficiency on the $1^{\text {st }}$ ratoon cane was $2.13 \mathrm{tCO}_{2}$ /tyield.

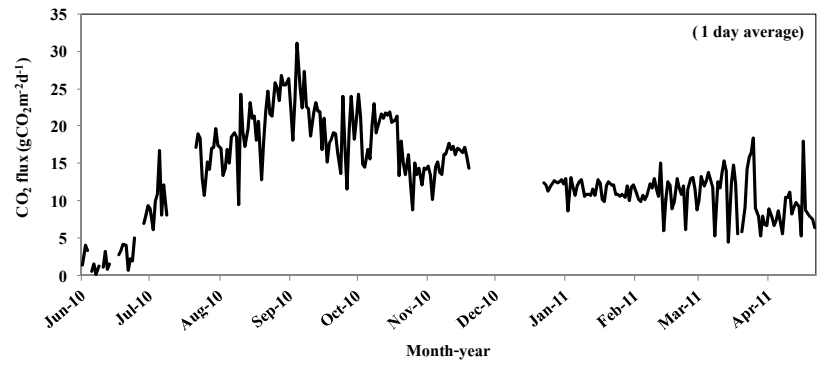

Fig. 7. Seasonal trend of $\mathrm{CO}_{2}$ flux of the first ratoon cane from 9 June 2010-30 April 2011.

\section{Discussion}

During the day time plant photosynthesis leads to uptake of $\mathrm{CO}_{2}$ from both the atmosphere and from respired $\mathrm{CO}_{2}$ emitted by the soil. Respiration at night leads to an efflux of $\mathrm{CO}_{2}$ to the atmosphere [13]. Reference [14] found that the carbon storage content of sugarcane plantation in one crop yield consists of the carbon storage in sugarcanes and the organic carbon deposits in the soil. This carbon storage content was increases when the sugarcane grows. The results were similar to the reported in paddy fields as in [15] found that $\mathrm{CO}_{2}$ flux was lower in stage I because of small LAI, then, gradually in increased and reached its maximum in the later stage. Moreover, $\mathrm{CO}_{2}$ flux decreased in stage IV, probably due to the leaf senescence. Net exchange of $\mathrm{CO}_{2}$ between crop community and the atmosphere is controlled by several biological and physical processes. It is well accepted that $\mathrm{CO}_{2}$ storage with in the forest canopy has to be taken into account wherever we discuss the net $\mathrm{CO}_{2}$ exchange between the ecosystem and the atmosphere [16].

\section{CONCLUSION}

During the night time the first ratoon cane was a $\mathrm{CO}_{2}$ source originating from plant and soil respiration and during the day time became a $\mathrm{CO}_{2}$ sink during the day time as plant photosynthesis advanced. However, for $24 \mathrm{hr}$ period, it was a $\mathrm{CO}_{2}$ sink. Different of $\mathrm{CO}_{2}$ flux was observed in each growing stage. And $\mathrm{CO}_{2}$ absorption in germination stage, tillering stage, stalk elongation stage and maturity stage was $63.1,838.2,2,448.3$ and $950.8 \mathrm{gCO}_{2} \mathrm{~m}^{-2}$, respectively. Totally $\mathrm{CO}_{2}$ absorbance which is $4,300.4 \mathrm{gCO}_{2} \mathrm{~m}^{-2}$ of the first ratoon cane was found. Carbon use efficiency of the $1^{\text {st }}$ ratoon cane was 2.13 tyield $/ \mathrm{tCO}_{2}$. From this result it was concluded that the $1^{\text {st }}$ ratoon sugarcane ecosystem is a sink of $\mathrm{CO}_{2}$.

\section{ACKNOWLEDGMENT}

This study was financially supported by the Office of the Cane and Sugar Board and Thai Research Found (TRF). Many thanks to Center of Thai-French Cooperation on Higher Education and Research (DORAS center) for their encouragement and field instrumentations. Finally, we are grateful to the Cane and Sugar Industry Promotion Center for providing the experimental plots and field assistance.

\section{REFERENCES}

[1] A. S. Marcelo, J. L. Jifon, J. A. G. Da Silva, and V. Sharma, "Use of physiological parameters as fast tools to screen for drought tolerance in sugarcane," Braz. J. Plant Physiol., vol. 19, no. 3, pp. 193-201, 2007. 
[2] Office of the Cane and Sugar Board. (September 2012). Report on Cane and Sugar Production 2011/12. [Online]. Available: http://www.ocsb.go.th/upload/journal/fileupload/923-3963.pdf.

[3] A. Carrara, A. S. Kowalsk, J. Neirynck, I. A. Janssens, J. C. Yuste, and R. Ceulemans, "Net ecosystem $\mathrm{CO}_{2}$ exchange of mixed forest in Belgium over 5 years," Agricultural and Forest Meteorology, vol. 104 pp. 209-227, 2003.

[4] N. Saigusa, S. Yamamoto, R. Hirata, Y. Ohtani, R. Ide, J. Asanuma, M. Gano, T. Hirano, H. Kondo, Y. Kosugi, S. G. Li, Y. Nakai, K. Takagi, M. Tani, and H. Wand, "Temporal and spatial variations in the seasonal patterns of $\mathrm{CO}_{2}$ fllux in boreal, temperature and tropical forests in East Asia," Agricultural and Forest Meteorology, vol. 148, no. 5, pp. 700-713, 2008

[5] M. Saito, A. Miyata, H. Nagai, and T. Yamada, "Seasonal variation of carbon dioxide exchange in rice paddy field in Japan," Agricultural and Forest Meteorology, vol. 135, pp. 93-109, 2005.

[6] T. Kuo-Hsin, J. Tsai, A. Alagesan, B. Tsuang, M. Yao, and P. Kuo, "Determination of methane and carbondioxide fluxes during the rice maturity period in Taiwan by combining profile and eddy covariance measurements," Agricultural and Forest Meteorology, vol. 150, pp. 825-859, 2010.

[7] A. P. Schrier-Uijl, P. S. Kroon, A. Hensen, P. A. Leffelaar, F. Berendse, and E. M. Veenendaal, "Comparision of chamber and eddy covariance-based $\mathrm{CO}_{2}$ and $\mathrm{CH}_{4}$ emission estimates in a heterogeneous grass ecosystem on peat," Agricultural and Forest Meteorology, vol. 150 , pp. 825-831, 2010.

[8] G. J. Gascho, "Water-sugarcane relationship," Sugar Journal, vol. 48, no. 6, pp. 11-17, 1985.

[9] S. Makoto, A. Miyata, H. Nagai, and T. Yamada, "Seasonal variation of carbon dioxide exchange in rice paddy field in Japan," Agricultural and Forest Meteorology, vol. 135, pp. 93-109, 2005.

[10] H. D. Evan, E. D. John, B. T. Richards, and G. M. Miquel, "Forest carbon use efficiency: is respiration a constant fraction of gross primary production?" Global Change Biology, vol. 13, pp. 1157-1167, 2007.

[11] J. S. Amthor, "The McCree-de Wit-Penning de Vries-Thornley Respiration Paradigms: 30 Years Later," Annals of Botany, vol. 86, pp. $1-20,2000$.

[12] R. M. Gifford, "The Global Carbon Cycle: A Viewpoint on the Missing Sink," Aust. J. Plant Physiol, vol. 21, pp. 1-15, 1994.

[13] A. Miyata, R. Leuning, O. T. Demeand, J. Kim, and Y. Harazono, "Carbon dioxide and methane fluxes from an intermittently flooded paddy field," Agricultural and Forest Meteorology, vol. 102, pp. 287-303, 2000.

[14] W. Watcharapirak, "The estimation of carbon storage in various growth stages of sugarcane in Sisatchanalai district, Sukhothai province, Thailand," Master Thesis, Mahidol University, Thailand, 2009.

[15] T. Pakoktom, M. Aoki, P. Kasemsap, S. Boonyawat, and P. Attarod, " $\mathrm{CO}_{2}$ and $\mathrm{H}_{2} \mathrm{O}$ fluxes ratio in paddy fields of Thailand and Japan," Hydrological Research Letter, vol. 3, pp. 10-13, 2009.

[16] M. Aubinet, B. Chermanne, M. Vandenhaute, B. Longdoz, M. Yernaux, and E. Laitat, "Long term carbon dioxide exchange above a mixed forest in the Belgian Ardennes," Agricultural and Forest Meteorology, vol. 108, pp. 293-315, 2001.

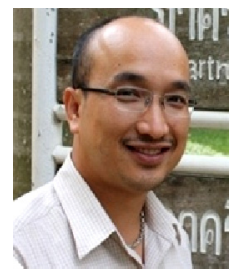

Tiwa Pakoktom was born in Thailand. He was awarded his Bachelor's and master's degree in Agronomy from the Department of Agronomy, Faculty of Agriculture, Kasetsart University, Thailand in 1995 and 2002, respectively. He graduated $\mathrm{PhD}$ in Science of Resources and Environment, United Graduate School of Agricultural Science, Tokyo University of Agriculture and Technology, Japan in 2009.

$\mathrm{He}$ is a lecturer in Agronomy Department, Faculty of Agriculture at Kamphaeng Saen, Kasersart University Kamphaeng Saen Campus, Thailand. His teaches in the field of Plant Climate, Water Management for Field Crops, Physiological of Field Crop Production, Advance Physiological of Field Crop Production and Crop Microclimate.

His research interests are prediction of weather and climate changes, global warning and agriculture, greenhouse gases emission and it's mitigation, gas flux measurement, plant stress by heat and drought and air pollutions.

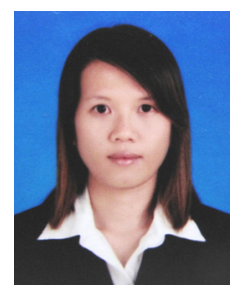

Nongpat Chaichana was born in Thailand. She graduated in bachelor's of science (Agriculture) majoring in Agronomy in 2003. Now she studying for M.S. degree at Department of Agronomy, Faculty of Agriculture at Kamphaeng Saen, Kasetsart University. She interested in research in global climate changes, global warming, greenhouse gas monitoring and warning system for agricultural risk.

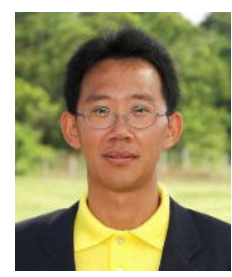

Jessada Phattaralerphong was born in Thailand. He was awarded his bachelor's degree in Agriculture First Class Honors from the Department of Horticulture, Faculty of Agriculture, Kasetsart University. His Master's degree in Agriculture from Kasetsart University. He graduated Ph.D in Botany from Kasetsart University, and Dr. (Physiologie Genetique Moleculaires) from Universite Clermont-Ferrand-II, France. In 2004-2005, he work ing to Development of photograph technique to estimate geometrical parameters of isolated tree. U.M.R. PIAF, Institut Nationale de la Recherche Agronomique (INRA), France.

Now, he is a lecturer in Faculty of Natural Resources and Agro-Industry, Kasetsart University Chalermphrakiat Sakonnakhon Province Campus. His research interests lie in plant architecture, plant physiology light, microclimate and gas flux measurement.

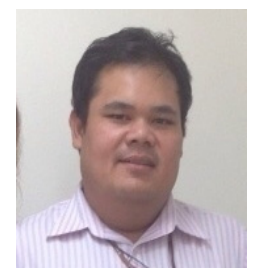

Jate Sathornkich was born in Thailand. He graduated Bachelor of Science (Plant Science) Mahidol University in 1999. He awarded his Master's degree in Botany and Doctor's degree in Tropical Agriculture from Kasetsart University in 2002 and 2008, respectively. He is now a researcher at Department of Horticulture, Faculty of Agriculture, Kasetsart University. He is a researcher with expertise in canopy structure, $\mathrm{CO}_{2}$ flux, plant architecture, plant physiology light and hemispherical photograph. 